\title{
Using DNA barcode to relate landscape attributes to small vertebrate roadkill
}

\author{
Karen Giselle Rodríguez-Castro ${ }^{1}$ - Giordano Ciocheti ${ }^{2}$ • \\ John Wesley Ribeiro ${ }^{2} \cdot$ Milton Cezar Ribeiro $^{2}$. \\ Pedro Manoel Galetti Jr. ${ }^{1}$
}

Received: 27 February 2016/Revised: 23 November 2016/Accepted: 5 January 2017/

Published online: 16 January 2017

(C) Springer Science+Business Media Dordrecht 2017

\begin{abstract}
Large vertebrates are the main focus of roadkill studies because their greater size facilitates taxonomic identification and the collection of statistical data. However, these studies fail to effectively include and identify small vertebrates and correlate roadkill events with the surrounding landscape. Here we showed the effectiveness of molecular data to identify small vertebrate roadkill, and we correlated landscape structure attributes with the location of roadkill for functional groups of varying mobility. The extraction of DNA from roadkilled individuals was followed by the amplification of two mitochondrial genes. We compared each DNA sequence to a database and used the highest similarity values for species identification. The species were classified according to their taxa and degree of mobility: birds, reptilia and amphibia with low and intermediate movement capability. After calculating the landscape attributes for each roadkill point, we used a competing model approach based on Akaike Information Criteria to determine which landscape variable best explained the occurrence of roadkills. Combining molecular and morphological characteristics, we identified $82.93 \%$ of the roadkilled animals. DNA barcoding allowed the identification of $310 \%$ more specimens than by morphological characteristics alone. Roadkilled birds with intermediate movement capability were strongly influenced by dominated areas by agriculture and sugar cane monocultures. Roadkilled reptiles with low movement capability were positively correlated with the presence of forest remnants, while those with intermediate movement capability seemed to be more
\end{abstract}

Communicated by Kirsty Park.

Electronic supplementary material The online version of this article (doi:10.1007/s10531-017-1291-2) contains supplementary material, which is available to authorized users.

Karen Giselle Rodríguez-Castro

karengiselle2004@gmail.com

1 Laboratório de Biodiversidade Molecular e Conservação, Departamento de Genética e Evolução, Universidade Federal de São Carlos (UFSCar), São Carlos, SP CEP 13565-905, Brazil

2 Laboratório de Ecologia Espacial e Conservação - LEEC, Departamento de Ecologia, Universidade Estadual Paulista (UNESP), Rio Claro, SP CEP 13506-900, Brazil 
frequent in heavily anthropized landscapes. We showed that molecular data is a powerful tool for precisely identifying small-sized roadkilled animals. Our results also highlight that different landscape structure attributes enable the prediction of roadkill occurrence along roads, which in turn allows us to identify roadkill hotspots and plan appropriate mitigation actions.

Keywords Functional groups · Species identification · Cytochrome oxidase I (COI) gene · $16 \mathrm{~S}$ gene

\section{Introduction}

Each species adapts differently to changes in their natural habitat. During their movements between heterogeneous areas, they face composite matrix, urban areas and roads (Fahrig 2003; Gorman and Raffaelli 2008). While crossing the matrix, they are exposed to various threats such as hunting or predation (Laurance et al. 2009), disease transmission (Cleaveland et al. 2001) and a high roadkill probability when traversing roads (Forman and Alexander 1998).

\section{Assessing roadkill effects on vertebrates}

Roadkill has become an issue for the maintenance of biodiversity and gene flow, particularly for those species that need to disperse or have suffered population reduction. Jackson and Fahrig (2011) showed that although the barrier effect of roads contributes to the reduction of genetic diversity, a reduction in population by roadkills has a higher impact. Species are differentially affected by roadkill: (a) species that have intermediate movement capability and that use heterogeneous matrix have the greatest probability of being killed (Beebee 2013); (b) large-bodied mammals with low reproductive rates and high mobility species have been indicated as those most afflicted by road effects (Rytwinski and Fahrig 2012); (c) the degree of mobility of bird species was key in defining their susceptibility to traffic effects, with the more mobile species being at greater risk (Rytwinski and Fahrig 2012); (d) species that do not cross roads or altered areas present lower roadkill probability (Hawbaker et al. 2006); (e) roads and traffic negatively influenced small-bodied frogs as well as toads with lower reproductive rates during the early years of sexual maturity (Rytwinski and Fahrig 2012).

Studies on roadkill focus mainly on the number of animal hits, i.e. the rate of hits per segment of road per time. Analyses of these data have revealed the effects of road types on mortality and on the spatial distribution of roadkilled vertebrates (Clevenger et al. 2003), the ecological effect of roads (Coffin 2007), the barriers created by roads and their effects on genetic diversity (Balkenhol and Waits 2009; Sork and Smouse 2006). Some studies also evaluated the response of wildlife to crossing structures (Bager and Fontoura 2013). While a large number of small individuals/species suffer road effects (ex. Clevenger et al. 2003; Glista et al. 2008; Gomes et al. 2009; Kociolek et al. 2011; Langen et al. 2009; Ramp et al. 2005; Shepard et al. 2008), they have not received attention until recently, because the loss of their morphological characteristics due to roadkill events makes taxon identification difficult. 


\section{DNA barcoding contribution to roadkill studies}

DNA barcoding become a powerful tool for bypassing the difficulty of identifying smallsized roadkilled animals quickly and accurately, which is crucial when morphological features are lost. In addition to accurate identification, the application of genetic markers using fauna samples from roadkill studies benefits the collection of information for conservation, e.g. the presence of rare and endangered species, or species-level identification when a large number of small individuals are hit (Clark et al. 2010; Klippel et al. 2015; Munshi-South 2012; Riley et al. 2006; Simmons et al. 2010; Taylor and Goldingay 2010).

Mitochondrial cytochrome c oxidase 1 (COI) gene is preferable for establishing the genetic barcode of species because its variety of phylogenetic signals has greater divergence between species than other mitochondrial genes, and it has been used to successfully identify new species (Hebert et al. 2004). Some studies have argued that there is no single gene for a universal barcode that pertains to all domains of life while also having sufficient divergence for species discrimination (Stoeckle 2003). The $16 \mathrm{~S}$ gene is suggested as an alternative locus for vertebrate barcoding (Vences et al. 2005a, b) and is proposed as supplementary to the COI gene in molecular identifications (Smith et al. 2008).

\section{Landscape as a roadkill predictor}

After species identification, statistical models can explain the relationship between their most frequent points of collision and the surrounding landscape. If we are able to predict the positions along the road where species are more prone to be killed due to the surrounding landscape structure of these positions, we can build a predictive model for estimating the roadkill probability of a species. We can then use this information to identify potential roadkill hotspots; such information is important not only for those road segments where we have roadkill information, but also for other segments without data (Clevenger et al. 2003; Laurance et al. 2009; Rytwinski and Fahrig 2012). The emphasis is on potential hotspots, because we are also interested in identifying areas without data, which is the case of many roads worldwide. Differences among landscapes and among species' movement capabilities warrant the use of functional groups (Fahrig and Rytwinski 2009) in models and allow a new perspective for data analysis.

In this study, we (a) used DNA barcoding to identify roadkilled species whose morphological characters were lost, and (b) correlated the location of roadkill species grouped by movement capacity, by the surrounding landscape structure. We predicted that the DNA barcoding method would contribute significantly to species-level identification of smallsized animals by distinguishing an increased number of carcasses, and that more roadkills would correlate to the surrounded landscape structure attributes, but that these attributes would vary depending on the species or their movement capacity. More specifically, we expected that: (1) DNA barcoding would significantly increase the number of identified individuals when compared to morphological identification; (2) all species would be equally identifiable by DNA barcoding, independent of the taxon, degree of mobility or gene used; (3) birds, reptilia and amphibia would be the taxa killed more frequently compared to mammalia; (4) species of intermediate mobility would have greater probability of being killed than those of low mobility, independent of the taxon; (5) the variety of landscape elements (forest, sugarcane and agriculture, urban, water body and swamps, forestry and pasture) surrounding the roadkill position would significantly contribute to the predictability of roadkills for each taxon and mobility level, but the relative contribution 
would vary between landscape elements, taxon and mobility; (6) roadkill frequency to be higher in areas of natural habitat (forest, water body and swamps) and lower adjacent to anthropogenic landscapes (urban, forestry, agriculture and pasture).

\section{Methods}

\section{Study area and data collection}

We collected roadkilled individuals on the Guilherme Scatena road (SCA-010, São Carlos$\mathrm{SP}$, Brazil), a single two-way road with a car speed limit of $60 \mathrm{~km} / \mathrm{h}(\sim 37 \mathrm{mph})$. The road is located between $21^{\circ} 59^{\prime} 27^{\prime \prime} \mathrm{S}$ and $21^{\circ} 54^{\prime} 55^{\prime \prime} \mathrm{S}$ latitude and, $47^{\circ} 52^{\prime} 57^{\prime \prime} \mathrm{W}$ and $47^{\circ} 48^{\prime} 57^{\prime \prime} \mathrm{W}$ longitude (Fig. 1), at an elevation of 750 m.a.s.l. Cerrado—a typical Brazilian savanna-is the predominant original vegetation in the region, which exhibits a high rate of species endemism (Klink and Machado 2005; Myers et al. 2000). Currently, however, the interior of São Paulo presents a high portion of human-modified lands and consequent habitat loss and fragmentation, with only about $7 \%$ of the vegetation remaining in the region (Ribeiro et al. 2009). The climate presents two dominant seasons throughout the year: a wet summer and a dry winter.

Using a motorcycle, a 12-km stretch of the road was searched for roadkill twice daily for 20 weeks during the summer (10) and winter (10) of 2010-2011. For each roadkilled individual discovered, we recorded its geographic coordinate using a GPS device and collected a tissue sample, preserving it in absolute ethyl alcohol. Every roadkill was photographed at the locale and properly transported to the laboratory. A specialist morphologically identified each sample to the most detailed taxonomic level possible.

\section{Molecular identification and species classification}

Total DNA of each sample was extracted according to the methodology described by Sambrook et al. (1989). We did PCR analysis in $25 \mu \mathrm{l}$ for molecular identification of the samples (50 ng of DNA; buffer tris- $\mathrm{KCl} 1 \times$ [Tris- $\mathrm{HCl} 20 \mathrm{mM} \mathrm{pH} 8.4$ and $\mathrm{KCl} 50 \mathrm{mM}$ ]; $2.0 \mathrm{mM}$ of $\mathrm{MgCl}_{2}$ [50 mM]; $0.3 \mu \mathrm{M}$ of each primer; $0.25 \mathrm{mM}$ of dNTPs; and 0.5 unit of Taq DNA Polymerase Platinum [Invitrogen]). We initially amplified the pair of universal primers LCO1490 (5'-GGTCAACAAATCATAAAGATATTGG-3') and HCO2198 (5'TAAACTTCAGGGTGACCAAAAAATCA-3') (Folmer et al. 1994) in order to amplify a fragment of mitochondrial cytochrome c oxidase subunit I (COI) gene (670 base pairs, bp). We used 16SarL (5'-CGCCTGTTTACCAAAAACAT-3') and 16SbrH (5'-CCGGTCTGA ACTCAGATCACGT-3') primer pair (Palumbi et al. 1991) to amplify the mitochondrial $16 \mathrm{~S}$ gene $(550 \mathrm{bp})$. Both mitochondrial genes were used to amplify all samples and compare results.

PCR conditions for $\mathrm{COI}$ included 4 min denaturation at $94{ }^{\circ} \mathrm{C} ; 5$ initial cycles of $4 \mathrm{~min}$ at $94{ }^{\circ} \mathrm{C} ; 90 \mathrm{~s}$ at $47{ }^{\circ} \mathrm{C} ; 60 \mathrm{~s}$ at $72{ }^{\circ} \mathrm{C} ; 40$ additional cycles of $60 \mathrm{~s}$ at $94{ }^{\circ} \mathrm{C} ; 90 \mathrm{~s}$ at $50{ }^{\circ} \mathrm{C}$; $60 \mathrm{~s}$ at $72{ }^{\circ} \mathrm{C}$; and elongation for $5 \mathrm{~min}$ at $72{ }^{\circ} \mathrm{C}$. We conducted $16 \mathrm{~S}$ PCR for $5 \mathrm{~min}$ denaturation at $94{ }^{\circ} \mathrm{C} ; 30$ cycles for $30 \mathrm{~s}$ at $94{ }^{\circ} \mathrm{C} ; 45 \mathrm{~s}$ at $57{ }^{\circ} \mathrm{C} ; 45 \mathrm{~s}$ at $72{ }^{\circ} \mathrm{C}$; and a final extension for $10 \mathrm{~min}$ at $72{ }^{\circ} \mathrm{C}$. All amplifications were checked on $2 \%$ agarose gel, including the negative controls and molecular weight marker. We purified PCR products with polyethylene glycol, following the protocol proposed by Sambrook and Russell (2001). For the obtained fragments, we used direct sequencing by the chain-termination 


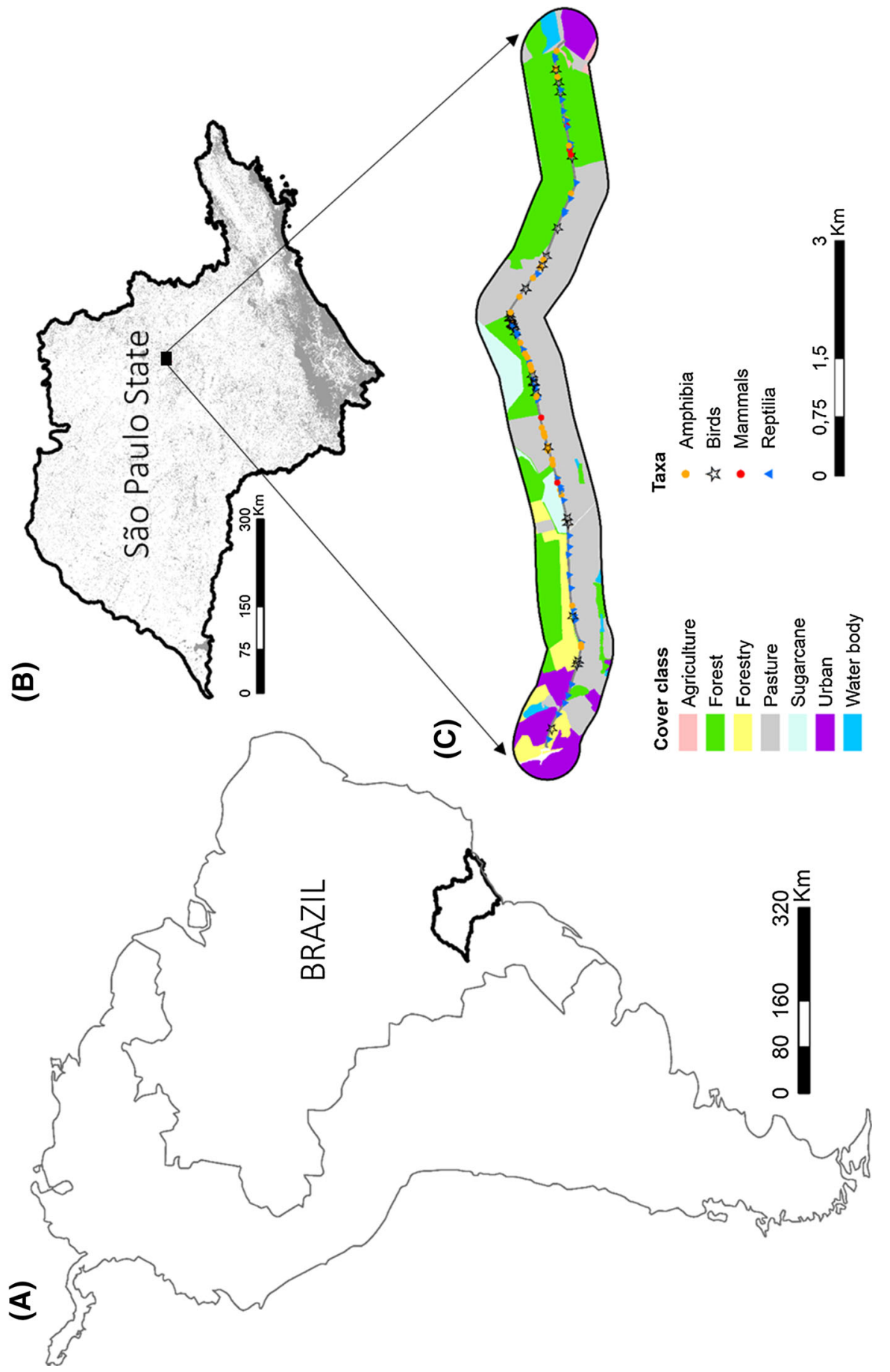


4Fig. 1 Roadkill points distribution of birds, reptilia, amphibia and mammals on a road segment and land cover types within highly fragmented and heterogeneous landscape, Guillerme Scatena Municipal Road, São Carlos-SP, Brazil. a Location of São Paulo State within Brazil and South America; b remaining vegetation of São Paulo State and the location of study area; c land use and land cover map within a buffer of $500 \mathrm{~m}$ around the studied road, where the roadkills for taxa area presented

reaction technique (Sanger et al. 1977) in the automatic sequencer ABI 3730xl DNA Analyzer. When necessary, the samples were repeated at least twice to ensure sequence accuracy and clear electropherograms.

The sequences were edited using the electropherograms and were aligned according to the Clustal method (Thompson et al. 1994) using the BioEdit software (Hall 2004). We compared each sequence to the databases of the National Center of Biotechnology Information (NCBI), using the Basic Local Alignment Search Tool (BLAST) (Altschul et al. 1990) and, for the COI gene, also using the Barcode of Life Data Systems database (BOLD). To prevent false identification comparisons, each gene was independently compared to each database. To establish the most likely species of each individual, we searched for sequences showing the highest similarity value, considering only values greater than $98 \%$. The most likely species was then compared to the photographic record made during data collection. We analyzed the species occurrence in the study area using the lists of species recorded in Brazil (Dos Reis et al. 2011; Sawaya et al. 2008; SBH 2010; Souza 1998). When a conflict emerged between COI or $16 \mathrm{~S}$ species identification, or when similarity values on databases were lower than $98 \%$, we identified to a level higher than species (genus, family, order). To identify the statistical difference between the number of individuals identified by morphological characters or by DNA barcode, we used a Chi square test, expecting that the DNA barcode and morphological characters would have the same resolution to identify species.

After species identification, we classified them according their taxa (birds, amphibia, reptilia or mammalia) and then according to their functional group, which considers the mobility of species. To determine each species' functional group based on their daily movement capability, we referred to information from species specialists and from the literature (Forester et al. 2006; Indermaur et al. 2009; Perry and Garland 2002), or to their taxonomic classification when species identification was not possible. Depending on the movement capability, we define two groups: low movement capability, for radius $<100 \mathrm{~m}$ of landscape influences around roadkills; and intermediate movement capability, for radius $>200 \mathrm{~m}$ of landscape influence (Table 1). The spatial extent, or buffer size, that should be considered as a scale of influence in a landscape ecology study has not been firmly established and often depends on the specialists' opinion. The species' natural history, the context in which observations are made and, in some cases, the ecological process or response variable of interest are important considerations when setting the buffer size. For example, when studying the variability of spatial patterns of urban-based landscape structure to predict urban bird diversity in the city of Belo Horizonte, Brazil, J. Pena (personal comm.) ascertained $160 \mathrm{~m}$ as the best spatial extent. (Boscolo and Metzger 2011) evaluated the influence of different spatial extents on forest-dependent occurrence within Brazilian Atlantic Forest and observed that the buffer sized varied from 600 to $1000 \mathrm{~m}$, depending on the species of interest. However, no multiple-scale analysis was done here, because it is beyond the scope of present study. Regarding the functional groups, many studies have used this approach for landscape-based research, though the method of species classification varies: birds classified according to their sensitivity to fragmentation [low, medium and high] (Martensen et al. 2012); mammals classified based on their 
Table 1 Taxonomic classification and functional groups according to movement capability of the roadkilled individuals surveyed at Guilherme Scatena Municipal Road, São Carlos-SP, Brazil

\begin{tabular}{|c|c|c|c|c|}
\hline Class & \multicolumn{2}{|l|}{ Species } & No. of samples & Movement capability \\
\hline \multirow[t]{20}{*}{ Birds } & \multicolumn{2}{|c|}{ Synallaxis frontalis ${ }^{\mathrm{c}}$} & 1 & Intermediate \\
\hline & \multicolumn{2}{|c|}{ Falco sparverius } & 1 & \\
\hline & \multicolumn{2}{|c|}{ Coryphospingus cucullatus } & 5 & \\
\hline & \multicolumn{2}{|c|}{ Turdus amaurochalinus } & 1 & \\
\hline & \multicolumn{2}{|c|}{ Aratinga leucophthalmus ${ }^{\mathrm{b}}$} & 1 & \\
\hline & \multicolumn{2}{|c|}{ Basileuterus culicivorus ${ }^{\mathrm{c}}$} & 1 & \\
\hline & \multicolumn{2}{|c|}{ Volantinia jacarina $^{\mathrm{c}}$} & 3 & \\
\hline & \multicolumn{2}{|c|}{ Guira guira } & 1 & \\
\hline & \multicolumn{2}{|c|}{ Columbina talpacoti } & 2 & \\
\hline & \multicolumn{2}{|c|}{ Synallaxis albescens ${ }^{\mathrm{c}}$} & 1 & \\
\hline & \multicolumn{2}{|c|}{ Turdus sp. } & 1 & \\
\hline & \multicolumn{2}{|c|}{ Furnarius rufus ${ }^{\mathrm{c}}$} & 1 & \\
\hline & \multicolumn{2}{|c|}{ Caprimulgus parvulus ${ }^{\mathrm{c}}$} & 2 & \\
\hline & \multicolumn{2}{|c|}{ Zonotrichia capensis ${ }^{\mathrm{c}}$} & 2 & \\
\hline & \multicolumn{2}{|c|}{ Phaethornis pretrei ${ }^{\mathrm{c}}$} & 1 & \\
\hline & \multicolumn{2}{|c|}{ Sporophila caerulescens } & 1 & \\
\hline & \multicolumn{2}{|c|}{ Crypturellus parvirostris ${ }^{\mathrm{b}}$} & 1 & Low \\
\hline & \multicolumn{2}{|c|}{ Gallus gallus ${ }^{\mathrm{c}}$} & 1 & \\
\hline & \multicolumn{2}{|c|}{ Cariama cristata $^{\mathrm{b}}$} & 2 & \\
\hline & \multicolumn{2}{|c|}{ Nothura maculosa ${ }^{\mathrm{c}}$} & 1 & \\
\hline \multirow[t]{13}{*}{ Reptilia $^{a}$} & Amphisbaenia & Amphisbaenidae ${ }^{c}$ & 9 & Low \\
\hline & \multirow[t]{4}{*}{ Lacertilia } & Ameiva ameiva ${ }^{\mathrm{c}}$ & 8 & Low \\
\hline & & Lizards & 5 & \\
\hline & & Mabuya dorsivittata ${ }^{\mathrm{c}}$ & 1 & \\
\hline & & Tupinambis merianae & 3 & Intermediate \\
\hline & \multirow[t]{8}{*}{ Squamata } & Snake & 4 & Intermediate \\
\hline & & Oxyrhopus guibei ${ }^{\mathrm{b}}$ & 9 & \\
\hline & & Bothrops neuwiedi ${ }^{\mathrm{c}}$ & 1 & \\
\hline & & Micrurus altirostris ${ }^{\mathrm{b}}$ & 1 & \\
\hline & & Crotalus durissus & 4 & \\
\hline & & Sibynomorphus mikanii ${ }^{\mathrm{c}}$ & 2 & \\
\hline & & Boa constrictor & 1 & \\
\hline & & Philodryas patagoniensis ${ }^{\mathrm{c}}$ & 1 & \\
\hline Amphibia & Bufo schneider & & 2 & Intermediate \\
\hline & Hyla albopunc & & 2 & Low \\
\hline & Scinax fuscova & & 20 & \\
\hline & Aplastodiscus & hranae & 1 & \\
\hline & Leptodactylus & $\operatorname{cus}^{\mathrm{c}}$ & 6 & \\
\hline & Physalaemus $n$ & ereri $^{\mathrm{c}}$ & 2 & \\
\hline & Physalaemus c & $e r i^{\mathrm{c}}$ & 2 & \\
\hline & Physalaemus c & ralis $^{\mathrm{c}}$ & 1 & \\
\hline & Hyla faber & & 1 & \\
\hline & Leptodactylus & & 1 & \\
\hline
\end{tabular}


Table 1 continued

\begin{tabular}{llcc}
\hline Class & Species & No. of samples & Movement capability \\
\hline Mammalia & Carnivora & 1 & High \\
& Oligoryzomys flavescens & Low \\
& Mus musculus & 3 & \\
& Cabassous unicinctus & 1 & \\
Total & & 123 & \\
\hline
\end{tabular}

a Additional classification within Reptilia, following the taxonomic classification in suborder (Lacertilia, Squamata and Amphisbaenia)

b Identified species using only morphological characters

c Identified species (or family, only in the case of Amphisbanidae) using only molecular characters

fragmentation sensitivity and mobility for roadkill analysis [low mobility sensitive, high mobility generalist, high mobility sensitive] (Ciocheti 2014; Ciocheti et al. in review). We excluded from the analysis mammals and amphibians with intermediate movement capability and birds with low movement capability, because the sample sizes $(6,2$ and 5 , respectively) were insufficient to perform statistical analyses.

\section{Land cover mapping and landscape metrics}

We plotted data points obtained by GPS on a QuickBird image (DigitalGlobe 2007) and Google Earth images (www.earth.google.com) using the Quantum GIS software (www. qgis.org). Through manual classification of Google Earth maps (1:10,000 scale), we classified the study area according to land use and vegetation cover-Agriculture and Sugarcane, Forest, Forestry (commercial eucalypt plantations), Pasture (for livestock), Urban Areas and Water Body (Fig. 1) -with a final resolution of $5 \mathrm{~m}$. First, polygons were manually digitalized at a scale of 1:5000 to ensure optimal definition of the boundaries of each landscape element (cover classes). The polygons were then manually associated with the land use and vegetation cover described above, by visual inspection. For small extent mapping, which is the case in our study, manual classification is superior to digital image processing and automated classification techniques (Da Silveira et al. 2016; Mendes et al. 2015; Muylaert et al. 2016).

\section{Landscape metrics calculation}

Using the land use and vegetation cover map and Arc Map 9.1 (ESRI 2007), we calculated the percentage of each cover class around each pixel. These percentage values were calculated based on the two spatial extents $(100$ and $200 \mathrm{~m})$ that were used in the analysis of functional group mobility (low or intermediate movement capability). The input map for the calculation cited above used a 5-m spatial resolution map as input. We extracted the percentage values of each land use and vegetation class for the points of roadkilled fauna. We also extracted the percentage values of cover classes for random points along the road; these random points were used as the null model. We were then able to test whether the percentage distribution of each cover class associated with roadkill points was similar to the distribution of random points along the road. The number of random points corresponded to the sample size for all roadkill points and for each functional group. Although 
roadkill can present nested patterns due to the influence of context where roadkill events occur, the studies that analyze this type of data do not assess spatial autocorrelation, because these nested patterns provide valuable information. For example, Dekker and Bekker (2010) evaluated the badger (Meles meles) road mortality in the Netherlands, without includes autocorrelation on their analysis across the country level assessment. Secco et al. (2014) analyzed the intentional snakés roadkill in Brazil also not used spatial correlation components on their study.

\section{Density of roadkills for the functional groups}

We calculated the density of roadkills per functional group for each pixel of road, using the Kernel Density function of Arc Map 9.1 (ESRI 2007). Kernel Density Function gives the relative proportion of roadkill points inside a search radius, divided by the area of the buffer around the pixel. We also used the two spatial extents of interest (100 and $200 \mathrm{~m}$ ) to calculated roadkill density per functional group.

\section{Data analysis}

\section{Roadkill spatial uniformity distribution along the road}

As the study road lacked significant curves (almost straight), we assumed that the traffic volume and the speed limit were constant; therefore, those variables were not considered in the analyses. Using the roadkill points as reference, we evaluated whether the spatial distribution of fauna hits along road differed significantly from a uniform spatial distribution $\left(\chi^{2}=1.92, \mathrm{P}=0.572 ; \mathrm{df}=57\right)$; see Dale and Fortin (2014) by randomly selected pixels of road (5-m spatial resolution), the sample size being equal to the number of roadkills. We then used the Chi square test to compare the number of roadkills per segment of $200 \mathrm{~m}$ (observed) against the number of random samples for the same segment (expected). However, when we consider the species' functional groups, the degree of uniformity of the roadkill distribution varied-intermediate mobility birds: $\chi^{2}=1.33$, $\mathrm{P}=0.423$, df $=57$; low mobility birds: $\chi^{2}=7.27, \mathrm{P}=0.032$, $\mathrm{df}=57$; low mobility reptiles: $\chi^{2}=4.19, \mathrm{P}=0.053$, $\mathrm{df}=57$; intermediate mobility reptiles: $\chi^{2}=3.40$, $\mathrm{P}=0.075$, df $=57$; low mobility amphibians: $\chi^{2}=5.02, \mathrm{P}=0.042$, $\mathrm{df}=57$. Thus, we performed analyses to determine whether this non-uniform distribution was related to the landscape; our findings are presented in the results.

\section{Distribution of percentage of cover classes for roadkills}

We tested the correlation between landscape variables, using the Spearman coefficient in the BioEstat 5.0 software (Ayres et al. 2007), to identify variable redundancy and to reduce multicollinearity. We then analyzed the distribution of each landscape variable for the observed roadkill points to test whether it differed from the null model, where uniform distribution is assumed for the same variable on the road. This analysis followed six steps: (a) select a functional group of interest; (b) extract the landscape variables (e.g. the amount of forest around every roadkill); (c) divide the range of that variable into five bins and count the number of roadkills per bin (i.e. observed frequencies); (d) select random pixels of the road (5-m spatial resolution) using the same sampling size as the functional group; (e) count the number of random points for the same bins (i.e. expected frequencies) 
generated in the step (c) above; (f) compare the observed and expected frequencies using Chi square tests for each functional group and landscape variable. When Chi square $\mathrm{P}$-values were very low (i.e. $\mathrm{P}<0.05$ ), the landscape variables related to the roadkills differed from a random distribution in the same environmental space as the variable. We tested six landscape variables - amount of forest (Forest); agriculture and sugar cane (Agriculture); water bodies and swamps (Water body); urban and rural buildings (Urban); eucalyptus plantation (Forestry); and pasture or bare soil (Pasture)—for each functional group in each taxon.

\section{Roadkills density and landscape structure}

We used a competing model approach (Burnham and Anderson 2002) to estimate the relative contribution of the percentage of each cover class to explain the roadkill densities as response variables. In this step, the sampling unit was each roadkill point for each functional group. The following explanatory variables (in percentages) were used to compose univariate models for explaining roadkill densities: (a) forest; (b) water bodies; (c) agriculture; (d) urban; (e) forestry; and (f) pasture (Table 2). We calculated the W statistic using Shapiro.test function of $\mathrm{R}$ to test for a normal distribution of the data, and finding that was the case. We then fitted the roadkill densities as a function of each explanatory variable using a generalized linear model GLM in R, finding that our data followed a normal distribution of residuals similar to Martensen et al. (2012). We included a null model among the competing models to simulate the absence of influence of the landscape on roadkill density. Akaike Information Criterion (AIC; Akaike 1974), and the most parsimonious model were selected (Burnham and Anderson 2002). AIC values were corrected for small samples (AICc). We used AIC to estimate the competing models' relative ability to explain the response variables, using the hypothesis that one model is better than the other, and calculated the difference between the AIC of each model and the best model with lowest AIC ( $\triangle \mathrm{AIC}$ ). We also estimated the weight of evidence (wAICc) that any of the models was the best.

We used the AICc to compare all models in each functional group and determine which models best explained the distribution of roadkills in each functional group. The best models had a $\triangle \mathrm{AIC}<2$ and presented the highest wAICc (Burnham and Anderson 2002; Johnson and Omland 2004).

Table 2 Variables related to land use and cover used to explain roadkill density (amount of roadkill divided by the number of pixels of road within search radius) within Guilherm Scatena Municipal Road, São CarlosSP, Brazil

\begin{tabular}{ll}
\hline Model & Variable \\
\hline Forest & Percentage of forest \\
Agriculture & Percentage of sugarcane and other types of crops \\
Water body & Percentage of water body and swamps \\
Urban & Percentage of rural buildings and urban areas \\
Forestry & Percentage of commercial eucalyptus plantations \\
Pasture & Percentage pasture for cattle raising and bare soil
\end{tabular}

The variables of percentages were calculated within the buffers of 100 and $200 \mathrm{~m}$ for species with low and intermediate mobility, respectively 


\section{Results}

\section{DNA barcode and functional groups}

During the 20-week sampling period, we found 123 roadkilled vertebrates (Table 1). Mitochondrial genes fragments were successfully amplified with the COI gene for 96 individuals and with $16 \mathrm{~S}$ gene for 103 individuals. We deposited the obtained sequences in the NCBI database under the accession numbers: JQ627200-JQ627300 for the 16S gene and JQ6273301-JQ6273384 for the COI gene. Despite the success in gene amplification and molecular identification for both genes, DNA amplification was not possible with either gene for 12 individuals, due to material degradation by prolonged exposure to environmental conditions, especially for Serpentes and Lacertilia suborders, with four and five samples, respectively.

Although the 16S gene had a higher number of amplifications than the COI gene, the COI gene identified more samples to species level: 54 individuals from 19 species $(46.34 \%$ of all species found) identified using the $16 \mathrm{~S}$ gene, and 66 individuals from 28 species $(68.29 \%)$ identified using the COI gene. Species identification for birds and mammals was more successful using the COI than the $16 \mathrm{~S}$, with 43.9 and $7.3 \%$, respectively. However, the opposite was observed for amphibians and reptiles (24.4\% for COI and 39.0\% for $16 \mathrm{~S}$ ), due to both the success in amplifications and the different quantity of data available for each group in the database records.

Overall, of the 123 roadkilled individuals found on the Guilherme Scatena Municipal Road, we were able to morphologically identify 28 individuals to species level, corresponding to 14 different species (34.15\% of all species found). Using the two genes (COI and $16 \mathrm{~S}$ ), we identified 87 individuals to species level, finding 37 species $(90.24 \%$ of all species found). Combining both morphological and molecular characteristics, we were able to identify 102 individuals from 41 species. Compared to the number of individuals identified by morphological characteristics, DNA barcoding identified $310 \%$ more individuals, which was highly significant $\left(\chi^{2}=30.27 ; \mathrm{P}>0.0001 ; \mathrm{df}=1\right)$. Morphological characteristics alone (28 identified individuals) contributed to the identification of only $17 \%$ of the total identified individuals (102), but this increase was not significant $\left(\chi^{2}=1.19 ; \mathrm{P}=0.275 ; \mathrm{df}=1\right)$. We were unable to identify 21 individuals to species level; instead, two of these individuals were identified to genus (Leptodactylus sp. and Turdus sp.), nine to family (Amphisbaenidae), and ten to order (five Lacertilia and four Squamata and one Carnivora) levels.

\section{Landscape influences analysis}

Spearman correlation coefficient showed no significant correlations between the explanatory variables, since the values were less than 0.5 ; thus, all variables were retained for subsequent analyses. The Chi square comparison with the uniform distribution (Table S1) showed significant differences for birds with low movement capability in the forest and on bare soil or pasture. Low mobility birds experienced higher aggregation of roadkill on the road positions near forests and lower road mortality on areas with predominance of bare soil, agriculture or pasture.

The linear model revealed that, for birds and amphibians with low movement capability, the models did not explain the location of roadkills (Table 3). However, birds with an intermediate movement capability were strongly influenced by agriculture and 
Table 3 Best-supported models for explaining influence of landscape structure on density of roadkill of functional groups within Guilherme Scatena Municipal Road, São Carlos-SP, Brazil

\begin{tabular}{|c|c|c|c|c|c|}
\hline \multirow[t]{2}{*}{ Model } & \multicolumn{2}{|l|}{ Birds } & \multicolumn{2}{|c|}{ Reptilia } & \multirow{2}{*}{$\begin{array}{l}\text { Amphibia } \\
\text { Low }\end{array}$} \\
\hline & Low & Intermediate & Low & Intermediate & \\
\hline Forest & $<0.001$ & 0.093 & 0.177 & 0.090 & $<0.001$ \\
\hline Agriculture & - & 0.245 & 0.116 & 0.073 & $<0.001$ \\
\hline Water body & $<0.001$ & 0.094 & 0.143 & 0.145 & $<0.001$ \\
\hline Urban & - & 0.164 & - & 0.255 & $<0.001$ \\
\hline Forestry & $<0.001$ & 0.086 & 0.138 & 0.095 & $<0.001$ \\
\hline Pasture & $<0.001$ & 0.096 & 0.151 & 0.237 & $<0.001$ \\
\hline Null & 1 & 0.074 & 0.141 & $<0.001$ & 0.898 \\
\hline
\end{tabular}

The values are the weight of evidence (wAICc) for each model. Low and Intermediate mobility for the taxa are indicated. All the models were fit using GLM models. Comparisons must be done within each column

sugar cane monoculture, with most of the roadkill points located in proximity to this land cover type. A high number of roadkilled reptiles with low movement capability were found in forest remnants, and roadkilled reptiles with intermediate movement capability were more frequent in heavily anthropized landscapes or landscapes with man-made constructions.

\section{Discussion}

\section{DNA barcoding increases roadkill species identification}

The number of roadkilled small animals in the study area may suggest that the road severely impacts the local fauna. A wide variety of animals around the world are roadkill victims (Coffin 2007); however, the majority of roadkill records represent large vertebrates, for which taxonomic identification and the collection of statistical data are easier than for small animals. If we also account for small animals, the roadkill rate in Brazil could reach 8.65 animals/km/year (Dornas et al. 2012). The high rate of roadkills demands that the impact on species be studied, particularly in biomes with a high rate of endemism. Such a study requires species identification and information on the characteristics of affected groups. Our results show that molecular identification at species level allowed the identification of $70.7 \%$ of the roadkilled animals collected for this study; the method's success depends on the quality of the sample, the amount of information in the molecular databases, and the genes chosen for amplification.

In studies analyzing different taxonomic groups, such as an assessment of roadkills, the use of universal primers is the best choice for DNA amplification. However, some genes perform better than others, depending on the taxonomic group. For amphibians, Vences et al. (2005b) showed that amplifications with universal primers for the $16 \mathrm{~S}$ gene were more reliable than those for the COI gene. However, the data we obtained for amphibians indicated high reliability for both genes. Although we identified an almost equal number of individuals through the use of either gene, most individuals identified by the COI gene belonged to the same species. The $16 \mathrm{~S}$ gene identified a wider variety of amphibian species; however, the absence of a specific database for the $16 \mathrm{~S}$ gene impaired the use of $16 \mathrm{~S}$ information for all major taxonomic groups. 


\section{Identification by functional groups}

Bird individuals usually die on impacts with a car windshield; they then fall on the shoulders of the road, where their bodies are protected from being run over repeatedly. This fact not only helped their morphological identification, but also aided the molecular identification of these samples, as the well-preserved biological material allowed the extraction of high quality DNA and efficient DNA amplification. The ease of molecular identification for this group was also due to the amount of information stored in the COI database.

On the other hand, amphibians - one of the taxonomic groups most affected by roadkill (Beebee 2013)_-lose most of their diagnostic features, making morphological identification almost impossible. We were unable to morphologically identify any of the species in this class, thus demonstrating that the use of the DNA barcode was decisive for amphibian roadkill identification. Moreover, the use of two mitochondrial genes and two public databases allowed us to identify $90 \%$ of the roadkilled amphibians (37 individuals), compared to $66.7 \%$ of species identified by Klippel et al. (2015) through only the COI gene and the BOLD database.

For all taxonomic groups, the combined use of both morphological and molecular characteristics was favorable, promoting fast and reliable species identification. However, we also obtained some false molecular identifications (three species) of related species that do not occur in the study area-for example, Cariama cristata was misidentified as Ciconia boyciana (88\% identity)—indicating a lack of previous information in the molecular database for a few of the studied species. It is important to highlight that the similarity values were lower than $97 \%$ in these cases. Clearly, a database bias exists, whereby a vast source of molecular information is available for some regions of the world, while for other regions, such as the Neotropics, the local fauna is under-represented.

\section{Movement capacity influences roadkill rates}

According to Fahrig (2007), species' movement throughout a landscape differs depending on their sensitivity and response to environmental changes. Species with an intermediate movement capability may be more vulnerable to mortality on roads than species with lower movement capability (Carr and Fahrig 2001), or they may show different relationships with the landscape. Additionally, Rytwinski and Fahrig (2012) stated that large-sized mammal species that present low reproductive rates and greater mobility were more negatively affected by roads. Miotto et al. (in review) observed the same effect on pumas: although the road network is not yet a barrier to their movement, the elimination of breeding males is catastrophic for the genetic diversity of the population, particularly in species with low reproductive rates, because the population cannot compensate for mortality through higher reproduction. Rytwinski and Fahrig (2012) also asserted that highly mobile birds were more negatively affected by roads than less mobile birds; furthermore, amphibians, reptiles in general, small-sized frogs and toads in the early years of sexual maturity suffered greater negative influence of roads and traffic. In our study, we found no uniformity in the roadkill distribution for the functional groups, and there were differences between the analyzed groups, which in some cases were related to landscape context. For example, birds exhibiting intermediate movement capability-or more mobile birds according to Rytwinski and Fahrig (2012)—were strongly influenced by the percentage of agriculture 


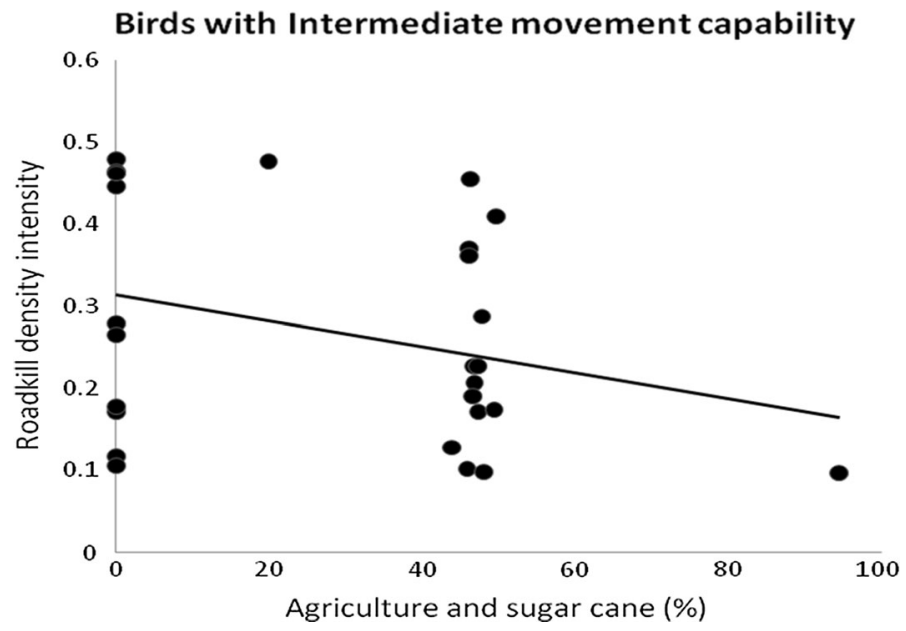

Fig. 2 Influence of percentage of agriculture and sugar cane on roadkill density for birds with intermediate movement capability within the Guilherme Scatena Municipal Road, São Carlos, SP, Brazil

and sugar cane monoculture (Fig. 2). Roadkilled reptiles with low movement capability were associated with forest remnants, while those exhibiting intermediate movement capabilities were more frequent in heavily anthropized landscapes. In the meta-analysis of Rytwinski and Fahrig (2012), the authors present information about the negative effects of roads on herpetofauna in general; however, while their discussion focuses on body size and reproductive phase, we are more interested in understanding how landscape structure influences the likelihood of species being killed on roads.

We found no relationship between amphibian roadkills and the presence of water bodies, contrary to the finding of Glista et al. (2008). Although we used high-resolution mapping, we were unable to map all watercourses and water bodies, possibly because many of them are hidden within dense vegetation. We did not identify any Cerrado endemic species, and most of the identified species that were associated with the major land cover classes are typically able to exist in human-modified habitat.

\section{Combining molecular and morphology-based identifications}

We confirmed the effectiveness of animal identification by means of molecular characters when there is a loss of morphological characteristics, as is the case for roadkilled individuals. The locations with the highest roadkill incidence were successfully identified using our molecular and morphology-based approaches. We related these locations to the position of animal carcasses and their surrounding landscape structure, testing the hypothesis that the frequency of roadkills differs significantly among functional groups, depending on the structure and composition of the surrounding landscape. Our study shows that most of the roadkilled animals are small. The presence of generalist species and the absence of Cerrado endemic fauna among roadkills may indicate the poor quality of this environment, which is heavily modified by human activities in the region (Ribeiro et al. 2016). Despite the negative effects of roads on fauna, roadkills can be an important source of (1) local wildlife information for records of species occurrence and (2) tissue samples from roadkilled animals for DNA studies; such data may benefit local fauna conservation. 
When planning roads and buildings, we emphasize the need to adopt a variety of approaches to mitigate roads impacts on the fauna, with particular consider of the different responses of the key functional groups of interest. For instance, birds with intermediate movement capability require the preservation of some sort of vegetation that enables them to adapt in an altered environment, while for lower movement capability reptiles, the priority should be the maintenance of as much native forests as possible, ideally more than 30\%, as suggested by Martensen et al. (2012) and Muylaert et al. (2016).

\section{Conclusions}

Wildlife loss due to roadkills is a global problem; however, roadkill analysis can contribute to the conservation of wildlife. Incorporating DNA analysis into roadkill studies means that much more data becomes available for ecological interpretation. Landscape analysis, related to the functional group of the identified species, also supports conservation through discovering the places with the highest incidence of roadkills. This information can contribute to wildlife conservation by informing roadkill mitigation strategies so that they can target the needs of specific taxonomic and functional groups. Below we present the top five mitigation strategies that we consider important for wildlife maintenance within a roadinfluenced context:

- Underpasses-e.g. (Administration 2002), open culverts (Goosem 2001) —for adapted fauna in order to reduce the number of small vertebrate roadkills.

- Pole barriers (Zuberogoitia et al. 2015) would be an appropriate strategy for birds of intermediate movement capability that are strongly influenced by agriculture and sugar cane monoculture; this measure would reduce the number of birds than die from impact with a windshield, because pole barriers, most of time, impede birds crossing the roads our stimualte them fly at higher height.

- Measures to control speed, such as speed bumps (Anon 1980) and increasing driver awareness with signs and pamphlets (Jones 2000), would reduce the number of low mobility roadkilled reptiles, which are related to forest remnants.

- Use of DNA barcode technique in roadkill studies to increase the number of identified species in roadkill analysis, which would aid in the selection of more appropriate mitigation measures.

- Further studies focused on functional groups and their relationship with the landscape, because there is a strong relationship between functional group and the type and location of mitigation strategy. Without this knowledge, road ecology with the purpose of the roadkill mitigation will be less effective for wildlife conservation.

Finally, we conclude that: (1) DNA barcoding increases the quality and amount of data that can be obtained in addition to those derived from morphological characteristics of fauna carcasses; (2) Landscape structure plays a crucial role for species most affected by roads, and we must combined roadkill data, DNA barcoding and landscape-based approaches to increase our understanding of how roads influence local and regional fauna maintenance; (3) Although roadkills are not desirable, the data generated is an important source of information about the biodiversity within any region, and these data this information is essential to the determination of mitigation strategies; (4) Despite the focus of many roadkill studies being a species-specific definition of mitigation strategies with a bias for medium and large-sized vertebrates, we advocate the adoption of functional group- 
based strategies for small-sized fauna (birds, reptiles, amphibians), because many species may have generally similar responses to roads within different landscape contexts.

Acknowledgements The authors thank Manoel Martins Dias Filho and Mercival Roberto Francisco for help with morphological animal identification. This research is part of the SISBIOTA Top Predators network. Karen Rodríguez-C and Pedro M. Galetti Jr thank the Brazilian agencies Conselho Nacional de Desenvolvimento Científico e Tecnológico $(\mathrm{CNPq})$ and Fundação de Amparo à Pesquisa do Estado de São Paulo (FAPESP) for financial support. Milton Cezar Ribeiro is funded by FAPESP (process 2013/50421-2) and $\mathrm{CNPq}$ research grants. We thank $\mathrm{M}$. King, a native English speaker from Canada, for proofreading the manuscript. Authors also thank anonymous reviewers for their useful comments and suggestions on previous versions of the manuscript.

\section{References}

Administration FH (2002) FHWA website. http://international.fhwa.dot.gov/wildlife_web.cfm

Akaike H (1974) A new look at the statistical model identification. IEEE Trans Autom Control 19:716-723. doi:10.1109/TAC.1974.1100705

Altschul SF, Gish W, Miller W, Myers EW, Lipman DJ (1990) Basic local alignment search tool. J Mol Biol 215:403-410

Anon (1980) Illinois snake crossing has traffic in a slither N Ohio Ass Herpetol 7

Ayres M, Ayres Jr M, Ayres DL, Santos AS (2007) Bioestat Versão 5.0

Bager A, Fontoura V (2013) Evaluation of the effectiveness of a wildlife roadkill mitigation system in wetland habitat. Ecol Eng 53:31-38. doi:10.1016/j.ecoleng.2013.01.006

Balkenhol N, Waits LP (2009) Molecular road ecology: exploring the potential of genetics for investigating transportation impacts on wildlife. Mol Ecol 18:4151-4164. doi:10.1111/j.1365-294X.2009.04322.x

Beebee TJ (2013) Effects of road mortality and mitigation measures on amphibian populations. Conserv Biol 27:657-668

Boscolo D, Metzger JP (2011) Isolation determines patterns of species presence in highly fragmented landscapes. Ecography 34:1018-1029. doi:10.1111/j.1600-0587.2011.06763.x

Burnham KP, Anderson DR (2002) Model selection and multi-model inference: a practical informationtheoretic approach. Springer, New York

Carr LW, Fahrig L (2001) Effect of road traffic on two amphibian species of differing vagility. Conserv Biol 15:1071-1078

Ciocheti G (2014) Spatial and temporal influences of road duplication on wildlife road kill using habitat suitability models. Universidade Federal de São Carlos

Ciocheti G, Assis JC, Ribeiro JW, Ribeiro MC Highway duplication and underpass influences on vertebrate road mortality, in review

Clark RW, Brown WS, Stechert R, Zamudio KR (2010) Roads, interrupted dispersal, and genetic diversity in timber rattlesnakes. Conserv Biol 24:1059-1069

Cleaveland S, Laurenson M, Taylor L (2001) Diseases of humans and their domestic mammals: pathogen characteristics, host range and the risk of emergence. Philos Trans R Soc B 356:991-999

Clevenger AP, Chruszcz B, Gunson KE (2003) Spatial patterns and factors influencing small vertebrate fauna roadkill aggregations. Biol Conserv 109:15-26

Coffin AW (2007) From roadkill to road ecology: a review of the ecological effects of roads. J Transp Geogr 15:396-406

Da Silveira NS, Niebuhr BBS, Muylaert RdL, Ribeiro MC, Pizo MA (2016) Effects of land cover on the movement of frugivorous birds in a heterogeneous landscape. PLoS ONE 11:e0156688. doi:10.1890/ $15-1757.1$

Dale MR, Fortin M-J (2014) Spatial analysis: a guide for ecologists. Cambridge University Press, Cambridge

Dekker JJ, Bekker HG (2010) Badger (Meles meles) road mortality in the Netherlands: the characteristics of victims and the effects of mitigation measures. Lutra 53:81-92

Dornas RAP, Kindel A, Bager A, Freitas SR (2012) Avaliação da mortalidade de vertebrados em rodovias no Brasil. In: Bager A (ed) Ecologia de estradas: tendências e pesquisas. UFLA, Lavras

Dos Reis NR, Peracchi AL, Pedro WA, Lima IP (2011) Mamíferos do Brasil; Mammals of Brazil. Universidade Estadual de Londrina, Londrina

ESRI (2007) ArcGis, the complete geographical information system, 9.1st edn. ESRI Press, Redlands 
Fahrig L (2003) Effects of habitat fragmentation on biodiversity. Ann Rev Ecol Evol Syst 34:487-515

Fahrig L (2007) Non-optimal animal movement in human-altered landscapes. Funct Ecol 21:1003-1015

Fahrig L, Rytwinski T (2009) Effects of roads on animal abundance: an empirical review and synthesis. Ecol Soc 14:21

Folmer O, Black M, Hoeh W, Lutz R, Vrijenhoek R (1994) DNA primers for amplification of mitochondrial cytochrome c oxidase subunit I from diverse metazoan invertebrates. Mol Mar Biol Biotech 3:294-299

Forester DC, Snodgrass JW, Marsalek K, Lanham Z (2006) Post-breeding dispersal and summer home range of female American toads (Bufo americanus). Northeast Nat 13:59-72

Forman RT, Alexander LE (1998) Roads and their major ecological effects. Ann Rev Ecol Syst 28:207-231

Glista DJ, DeVault TL, DeWoody JA (2008) Vertebrate road mortality predominantly impacts amphibians. Herpetol Conserv Biol 3:77-87

Gomes L, Grilo C, Silva C, Mira A (2009) Identification methods and deterministic factors of owl roadkill hotspot locations in Mediterranean landscapes. Ecol Res 24:355-370. doi:10.1007/s11284-008-0515-Z

Goosem M (2001) Effects of tropical rainforest roads on small mammals: inhibition of crossing movements. Wildl Res 28:351-364. doi:10.1071/WR99093

Gorman ML, Raffaelli D (2008) The functional role of wild mammals in agricultural ecosystems. Mamm Rev 38:220-230

Hall T (2004) Bioedit sequence alignment editor, 7.0.0. edn.,

Hawbaker TJ, Radeloff VC, Clayton MK, Hammer RB, Gonzalez-Abraham CE (2006) Road development, housing growth, and landscape fragmentation in northern Wisconsin: 1937-1999. Ecol Appl 16:1222-1237

Hebert PD, Penton EH, Burns JM, Janzen DH, Hallwachs W (2004) Ten species in one: DNA barcoding reveals cryptic species in the neotropical skipper butterfly Astraptes fulgerator. Proc Natl Acad Sci USA 101:14812-14817

Indermaur L, Gehring M, Wehrle W, Tockner K, Naef-Daenzer B (2009) Behavior-based scale definitions for determining individual space use: requirements of two amphibians. Am Nat 173:60-71

Jackson ND, Fahrig L (2011) Relative effects of road mortality and decreased connectivity on population genetic diversity. Biol Conserv 144:3143-3148

Johnson JB, Omland KS (2004) Model selection in ecology and evolution. Trends Ecol Evol 19:101-108

Jones ME (2000) Road upgrade, road mortality and remedial measures: impacts on a population of eastern quolls and Tasmanian devils. Wildl Res 27:289-296

Klink CA, Machado RB (2005) Conservation of the Brazilian cerrado. Conserv Biol 19:707-713

Klippel AH et al (2015) Using DNA barcodes to identify road-killed animals in two atlantic forest nature reserves, Brazil. PLoS ONE 10:e0134877

Kociolek A, Clevenger A, St Clair C, Proppe D (2011) Effects of road networks on bird populations. Conserv Biol 25:241-249

Langen TA, Ogden KM, Schwarting LL (2009) Predicting hot spots of herpetofauna road mortality along highway networks. J Wildl Manag 73:104-114. doi:10.2193/2008-017

Laurance WF, Goosem M, Laurance SG (2009) Impacts of roads and linear clearings on tropical forests. Trends Ecol Evol 24:659-669

Martensen AC, Ribeiro MC, Banks-Leite C, Prado PI, Metzger JP (2012) Associations of forest cover, fragment area, and connectivity with Neotropical understory bird species richness and abundance. Conserv Biol 26:1100-1111

Mendes CP, Ribeiro MC, Galetti M (2015) Patch size, shape and edge distance influence seed predation on a palm species in the Atlantic forest. Ecography 39:465-475. doi:10.1111/ecog.01592

Miotto RA, Desbiez A, Ferraz K Viability of a top predator, the puma (Puma concolor), in a humandominated landscape in Brazil, in review

Munshi-South J (2012) Urban landscape genetics: canopy cover predicts gene flow between white-footed mouse (Peromyscus leucopus) populations in New York City. Mol Ecol 21:1360-1378

Muylaert RL, Stevens RD, Ribeiro MC (2016) Threshold effect of habitat loss on bat richness in cerradoforest landscapes. Ecol Appl. doi:10.1890/15-1757.1

Myers N, Mittermeier RA, Mittermeier CG, Da Fonseca GA, Kent J (2000) Biodiversity hotspots for conservation priorities. Nature 403:853-858

Palumbi S, Martin A, Romano S, McMillan W, Stice L, Grabowski G (1991) The simple fool's guide to PCR, version 2.0, privately published document compiled by S. Palumbi. Dept Zoology, Univ Hawaii, Honolulu

Perry G, Garland T Jr (2002) Lizard home ranges revisited: effects of sex, body size, diet, habitat, and phylogeny. Ecology 83:1870-1885

Ramp D, Caldwell J, Edwards KA, Warton D, Croft DB (2005) Modelling of wildlife fatality hotspots along the snowy mountain highway in New South Wales. Aust Biol Conserv 126:474-490 
Ribeiro MC, Metzger JP, Martensen AC, Ponzoni FJ, Hirota MM (2009) The Brazilian Atlantic Forest: how much is left, and how is the remaining forest distributed? Implications for conservation. Biol Conserv 142:1141-1153

Ribeiro MC et al (2016) Dealing with Fragmentation and Road Effects in Highly Degraded and Heterogeneous Landscapes. In: Gheler-Costa C, Lyra-Jorge MC, Martins Verdade L (eds) Biodiversity in agricultural landscapes of southeastern Brazil. De Gruyter Open, Warsaw, pp 43-64. doi:10.1515/ 9783110480849-006

Riley SP, Pollinger JP, Sauvajot RM, York EC, Bromley C, Fuller TK, Wayne RK (2006) A southern California freeway is a physical and social barrier to gene flow in carnivores. Mol Ecol 15:1733-1741. doi:10.1111/j.1365-294X.2006.02907.x

Rytwinski T, Fahrig L (2012) Do species life history traits explain population responses to roads? A metaanalysis. Biol Conserv 147:87-98

Sambrook J, Russell DW (2001) Molecular cloning: a laboratory manual, 3rd edn. Cold Spring Harbor Laboratory Press, New York

Sambrook J, Fritsch EF, Maniatis T (1989) Molecular cloning: a laboratory manual, 2a edn. Cold Spring Harbor Laboratory Press, New York

Sanger F, Nicklen S, Coulson AR (1977) DNA sequencing with chain-terminating inhibitors. Proc Natl Acad Sci 74:5463-5467

Sawaya RJ, Marques OAV, Martins M (2008) Composition and natural history of a Cerrado snake assemblage at Itirapina, São Paulo state, southeastern Brazil. Biota Neotrop 8:127-149

SBH SBdH (2010) Brazilian amphibians-list of species. Sociedade Brasileira de Herpetologia. http://www. sbherpetologia.org.br

Secco H, Ratton P, Castro E, da Silva PL, Bager A (2014) Intentional snake road-kill: a case study using fake snakes on a Brazilian road. Trop Conserv Sci 7:561-571

Shepard DB, Dreslik MJ, Jellen BC, Phillips CA (2008) Reptile road mortality around an oasis in the Illinois corn desert with emphasis on the endangered eastern massasauga. Copeia 2008:350-359. doi:10.1643/ CE-06-276

Simmons JM, Sunnucks P, Taylor AC, van der Ree R (2010) Beyond roadkill, radiotracking, recapture and FST - a review of some genetic methods to improve understanding of the influence of roads on wildlife. Ecol Soc 15:9

Smith M, Poyarkov NA, Hebert PD (2008) DNA barcoding: CO1 DNA barcoding amphibians: take the chance, meet the challenge. Mol Ecol Res 8:235-246

Sork VL, Smouse PE (2006) Genetic analysis of landscape connectivity in tree populations. Landsc Ecol 21:821-836

Souza D (1998) Todas as Aves do Brasil—Guia de campo para Identificação. Feira de Santana

Stoeckle M (2003) Taxonomy, DNA, and the bar code of life. BioScience 53:796-797

Taylor BD, Goldingay RL (2010) Roads and wildlife: impacts, mitigation and implications for wildlife management in Australia. Wildl Res 37:320-331

Thompson JD, Higgins DG, Gibson TJ (1994) CLUSTAL W: improving the sensitivity of progressive multiple sequence alignment through sequence weighting, position specific gap penalties and weight matrix choice. Nucl Acids Res 22:4673-4680. doi:10.1093/nar/22.22.4673

Vences M, Thomas M, Bonett RM, Vieites DR (2005a) Deciphering amphibian diversity through DNA barcoding: chances and challenges. Philos Trans R Soc B 360:1859-1868

Vences M, Thomas M, Van der Meijden A, Chiari Y, Vieites DR (2005b) Comparative performance of the 16S rRNA gene in DNA barcoding of amphibians. Front Zool 2:5

Zuberogoitia I et al (2015) Testing pole barriers as feasible mitigation measure to avoid bird vehicle collisions (BVC). Ecol Eng 83:144-151. doi:10.1016/j.ecoleng.2015.06.026 